\title{
ANALISIS WACANA PESAN DAKWAH DI MEDIA TELEVISI: STUDI PADA CERAMAH MAMAH DEDEH "POLIGAMI BISAKAH ADIL?"
}

\author{
Eko Agoes Setiawan \\ STID Al-Hadid, Surabaya \\ eko.agoes92@gmail.com
}

\begin{abstract}
Abstrak: Wacana dan media tidak dapat dipisahkan. Setiap berita yang disampaikan oleh media selalu memiliki wacana untuk para pembacanya. Salah satu wacana yang seringkali menuai pro dan kontra adalah poligami. Banyak bentuk dukungan dan penolakan yang dilakukan yakni melalui media sosial, pembuatan komunitas pro maupun kontra poligami, aksi demo maupun sampai dengan debat terbuka mengenai poligami. Studi ini hendak menganalisis posisi perempuan dalam wacana poligami Mamah Dedeh yang ditayangkan di televisi dalam acara "Mamah dan Aa Beraksi" dengan tema "Poligami Bisakah Adil." Pengamatan dilakukan dalam ceramah maupun dialog interaktif dengan penonton dalam acara tersebut dengan tujuan ingin mengetahui apakah perempuan menurut Mamah Dedeh memiliki kebebasan untuk menolak/menerima dipoligami oleh laki-laki. Studi ini menggunakan pendekatan kualitatif dengan kerangka teori analisis wacana Sara Mills. Kesimpulan yang didapatkan bahwa perempuan tidak memiliki kebebasan untuk menolak dipoligami oleh laki-laki, ia harus menuruti dan ikhlas jika dipoligami oleh suaminya karena perempuan memiliki kewajiban untuk taat dan melayani suaminya.
\end{abstract}

Kata kunci: analisis wacana Sara Mills, poligami, Mamah Dedeh

\begin{abstract}
Discourse and media can be separated. Each news conveyed by media always contains a discourse for its readers. One of the discourses which frequently emerge pros and cons is polygamy. There are a lot of supports and refusals coming from social media, the establishment of communities of both pro and con of polygamy, demonstrations and open debate about it. This study is intended to analyze the position of a woman in Mamah Dedeh's polygamy discourse aired on television in the show "Mamah and Aa Beraksi" with the theme "Poligami Bisakah Adil." Observation was conducted within the sermon and interactive dialogs with the audience in the show with the aim of finding out whether a woman, according to Mamah Dedeh, has a freedom to refuse / accept to be married to more than one by men. This study uses qualitative approach with the theoretical framework of Sara Mills' discourse analysis. It concludes that a woman does not have any freedom to refuse of being married to more than one by men. They have to comply with and be sincere if she is married to more than one by her husband because she has an obligation to obey and serve her husband.
\end{abstract}

Key words: Sara Mills' discourse analysis, polygamy, Mamah Dedeh

\section{Pendahuluan}

Dalam kehidupan sehari-hari, seluruh akses informasi disajikan dan didapatkan dari berbagai media, baik cetak maupun online.
Media menjadi saluran yang penting bagi kehidupan masyarakat saat ini. Media dan wacana tidak bisa dipisahkan, Ismail Marahimin menjelaskan wacana sebagai 
kemampuan untuk maju (dalam pembahasan) menurut urutan yang teratur dan semestinya dan komunikasi buah pikiran, baik lisan maupun tulisan. Terdapat dua unsur penting dalam sebuah wacana yakni kesatuan dan kepaduan. ${ }^{1}$ Penjelasan tersebut memberikan arti bahwa wacana adalah studi mengenai bahasa atau pemakaian bahasa dalam sebuah komunikasi yang bersifat berurutan atau logis. Di sisi lain, media sebagai sarana informasi masyarakat memiliki kemampuan untuk membentuk dan mengarahkan opini publik karena media bukanlah pihak yang bebas, independen, melainkan sangat erat hubungannya dengan kepentingan.

Salah satu permasalahan yang tidak luput dari pemberitaan media adalah masalah poligami. Masalah poligami adalah salah satu masalah yang banyak pro dan kontra di kalangan umat muslim. Menarik bagi kaum laki-laki yang mungkin menjadikan sebagai obsesi hidup, namun juga bagi perempuan yang menganggap poligami sebagai sesuatu yang bisa membahayakan kedudukan di dalam sebuah rumah tangga. ${ }^{2}$ Pertentangan kalangan yang pro dan kontra dengan poligami ini bisa kita lihat dari beberapa realitas yang terjadi di masyarakat. Di sisi kelompok yang pro terdapat beberapa usaha untuk mempromosikan poligaminya kepada masyarakat, salah satu caranya adalah membentuk Klub Poligami Ikhwan.

${ }^{1}$ Alex Sobur, Analisis Teks Media: Suatu Pengantar untuk Analisis Wacana, Analisis Semiotik, dan Analisis Framing (Bandung: Reamaja Rosdakarya, 2009), 10.

2 Agus Sunaryo, "Poligami di Indonesia (Sebuah Analisis Normatif-Sosiologis)," Jurnal Studi Gender \& Anak, Vol. 5 No. 1 (Januari-Juni 2010):143.

${ }^{3}$ Shinta Dewi Rismawati, "Persepsi Poligami di Mata Perempuan Pekalongan," Jurnal Muwazah, Vol. 6 No. 2 (Desember 2014): 251.

4 Mohamad Sahril, "Begini Alasan Kampanye Kelompok Poligami Sakinah" pojoksatu.id, diakses 16 Agustus

2017,
Kelompok ini memiliki anggota sekitar 300 orang yang tersebar di Indonesia dan juga luar negeri. ${ }^{3}$ Selain itu juga ada pembentukan komunitas Poligami Sakinah Grup yang berbasis pada media sosial. Anggota komunitas ini sudah mencapai 270 orang. Kelompok ini berdiri karena merasa bahwa kebutuhan masyarakat yang ingin berpoligami tidak diakomodasi oleh pemerintah. $^{4}$

Realitas lainnya juga menunjukkan adanya usaha-usaha untuk menyebarkan praktik poligami, yaitu dengan adanya deklarator Klub Taat Suami. Dalam klub ini mengajarkan bahwa seorang istri harus menaati suami, termasuk jika suaminya ingin menikah lagi. Total anggota klub ini diperkirakan sebanyak lima ratus keluarga. ${ }^{5}$ Selain itu, permasalahan poligami juga menjadi perhatian publik. Beberapa kali dilakukan debat terbuka poligami dengan mendatangkan berbagai kalangan yang mendukung dan menolak poligami. Kalangan tersebut terdiri dari aktivis, perwakilan institut, maupun lembaga pemerintahan. ${ }^{6}$

Kelompok yang menolak adanya poligami juga memiliki beberapa aksi, di antaranya, di Medan, pada saat memperingati Hari Kartini, dimanfaatkan oleh belasan wanita dan ibu-ibu untuk menentang praktik poligami. Acara ini digelar karena mereka

http://pojoksatu.id/news/2015/03/27/begini-alasankampanye-kelompok-poligami-sakinah/

${ }^{5}$ Wisnu Agung Prasetyo, “Dr. Gina Puspita, Deklarator Klub Taat Suami: Poligami itu Bukan Suami yang Suruh" Tempo.co, diakses 16 Agustus 2017, https://m.tempo.co/read/news/2011/06/26/001343 303/dr-gina-puspita-deklarator-klub-taat-suamipoligami-itu-bukan-suami-yang-suruh

6 Andi Budiman, "Dialog Terbuka Poligami" Liputan6.com, diakses 16 Agustus 2017, http://news.liputan6.com/read/134087/dialogterbuka-poligami 
merasa bahwa poligami tidak memihak kaum perempuan. ${ }^{7}$ Acara serupa juga digelar oleh ratusan aktivis perempuan dari berbagai lembaga perempuan di Yogyakarta. Mereka melakukan demo saat hari Perempuan Internasional. Dalam acara tersebut, mereka menyuarakan menolak adanya praktik poligami dan nikah siri yang banyak terjadi di masyarakat. ${ }^{8} \mathrm{Di}$ Nusa Tenggara Barat (NTB) juga ada penolakan poligami, kegiatan ini dilakukan oleh ratusan ibu yang tergabung dalam Forum Peduli Perempuan Nusa Tenggara Barat (NTB), di depan kantor bupati, mereka menyuarakan bahwa poligami mencederai harga diri perempuan, karena menurut mereka ijin poligami Pegawai Negeri Sipil (PNS) dijadikan komoditi pemerintah daerah setempat. ${ }^{9}$

Penolakan terhadap poligami tidak hanya dilakukan melalui aksi demo di jalan-jalan. Salah satu hal yang dilakukan adalah memberikan bukti bahwa poligami memberikan dampak yang buruk bagi kaum perempuan. Dalam beberapa penelitian yang dilakukan, juga ditemui bahwa dampak poligami selalu merugikan kaum perempuan. Baik dalam bentuk kekerasan fisik maupun psikis termasuk juga dalam hal ekonomi. Ditemukan juga bahwa laki-laki yang melakukan poligami tidak memenuhi kewajiban untuk menafkahi, bahkan sang istri yang menafkahi suaminya. ${ }^{10}$

7 Yan Muhardiansyah, "Belasan Wanita Cantik Bercelana Jin Ketat Demo Tolak Poligami" Merdeka.com, diakses 16 Agustus 2017, https://www.merdeka.com/peristiwa/belasanwanita-cantik-bercelana-jin-ketat-demo-tolakpoligami

${ }^{8}$ Wijaya Kusuma, "Aktivis Perempuan Demo Tolak Poligami dan Nikah Siri" Kompas.com, diakses 16 Agustus 2017, http://nasional.kompas.com/read/2013/03/08/1210 469/aktivis.perempuan.demo.tolak.poligami.dan.nika h.siri
Perbedaan pendapat mengenai poligami tidak hanya terjadi pada masyarakat kekinian, namun hal ini sudah menjadi sejak zaman dahulu, terutama di kalangan para ulama sendiri. Para ulama klasik ada yang memperbolehkan praktik poligami dengan memberikan beberapa syarat. Syarat yang selalu ada dan menjadi kesamaan pendapat ulama klasik adalah mengenai aspek keadilan terhadap istri. Jika hal ini tidak bisa dipenuhi oleh suami, maka sebaiknya tidak melakukan poligami. ${ }^{11}$ Sedangkan kalangan ulama kontemporer memiliki pandangan memperbolehkan dan ada yang tidak memperbolehkan. Ulama yang memperbolehkan mendasarkan pada adanya aspek keadilan yang dijamin oleh seorang suami kepada istrinya. Tanpa aspek adil maka haram melakukan poligami. Sedangkan yang menolak poligami berpendapat bahwa praktik poligami adalah perilaku pra-Islam, yang di masa itu sangat berbeda dengan kondisi saat ini. Beberapa kalangan ulama yang menolak poligami ini juga masih memberikan ruang untuk poligami namun harus dalam kondisi yang sangat spesifik seperti istri tidak bisa menghasilkan keturunan, namun aspek keadilan tetap menjadi dasar dalam menjalankan poligami. ${ }^{12}$

Penjelasan realitas di atas menunjukkan bahwa perdebatan poligami sudah terjadi

\footnotetext{
${ }^{9}$ Tribunnews, "Wanita Lombok Demo Tolak Poligami Bayar Rp 1 Juta" Tribunnews.com, diakses 16 Agustus 2017,

http://wartakota.tribunnews.com/2014/10/24/wanit a-lombok-demo-tolak-poligami-bayar-rp-1-juta 10 Rismawati, Persepsi Poligami., 252.

11 Fathonah, "Telaah Poligami: Perspektif Ulama Populer Dunia (Dari Ulama Klasik hingga Ulama Kontemporer)," Al-Hikmah Jurnal Studi Kelslaman, Vol. 5 No. 1 (Maret 2015): 22-25.

12 Ibid., 28-34
} 
sejak zaman dahulu dan hingga kini. Dalam realitas juga selalu menunjukkan bahwa selalu ada setidaknya dua kelompok yang terbentuk, yakni pihak-pihak yang menolak praktik poligami dan juga pihak-pihak yang menerima bahkan melakukan praktik poligami. Setiap pihak selalu memberikan argumen mengapa poligami tidak boleh atau boleh dilakukan. Berkaitan dengan fenomena pro kontra poligami di masyarakat. Pada 8 Oktober 2015 dalam acara dakwah "Mamah Aa Beraksi," penceramah yang akrab disapa Mamah Dedeh membawakan ceramah dengan materi berjudul "Poligami Bisakah Adil". Materi yang dibawakan memiliki asumsi pro kontra dalam masyarakat, hal ini tentu menjadi pertanyaan kira-kira bagaimana pandangan Mamah Dedeh terhadap perilaku poligami itu sendiri, khususnya pandangan Mamah Dedeh terhadap perempuan sebagai pihak yang dikenai perilaku diduakan oleh suaminya.

Acara "Mamah Aa Beraksi" merupakan acara dakwah yang sedang digemari oleh masyarakat. Acara dakwah ini menduduki peringkat tiga dalam dimensi top of mind pemirsa, sebesar $13 \%$ di bawah acara dakwah "Islam Itu Indah." 13 Studi ini menjadi menarik karena Mamah Dedeh menjadi salah satu tokoh dakwah yang cukup familiar dikenal masyarakat. Dalam beberapa kesempatan Mamah Dedeh juga muncul dalam sebuah iklan produk. Hal ini bisa menjadikan indikasi bahwa daya tarik dan pengaruh Mamah Dedeh bagi masyarakat Indonesia bisa dipandang cukup baik. Secara logika seorang yang dijadikan

\footnotetext{
13 Mohammad Nurrokim, "Analisis Brand Awareness dan Brand Association Acara Dakwah di Televisi," Jurnal Kajian \& Pengembangan Managemen Dakwah, Vol. 03 No. 02 (Desember 2013): 42.
}

figur iklan adalah tokoh-tokoh yang memiliki pengaruh terhadap perilaku masyarakat. $\mathrm{Di}$ sisi lain Mamah Dedeh adalah seorang perempuan yang merupakan pihak yang kadang merasa dirugikan dengan adanya praktik poligami. Atas dasar latar belakang masalah di atas, fokus studi ini adalah mengidentifikasi posisi perempuan dalam wacana poligami yang disampaikan oleh Mamah Dedeh, apakah memiliki independensi (bebas) menolak/menerima perilaku dipoligami oleh suaminya. Adapun tujuan dari studi ini adalah mengetahui posisi perempuan sebagai subjek yang dikenai poligami bebas menolak praktik tersebut atau tidak.

Kerangka teori analisis wacana akan menggunakan pendekatan analisis wacana kritis Sara Mills. Wacana ini dipilih karena Sara Mills memfokusi pada aspek wacana mengenai feminisme yaitu bagaimana wanita ditampilkan dalam teks, baik dalam novel, gambar, foto atau pun dalam berita. Wacana ini juga sebenarnya bisa digunakan untuk menganalisis teks yang lebih luas dengan memfokuskan pada penempatan aktor dalam teks yakni siapa yang menjadi pihak penafsir dan pihak mana yang menjadi objek yang ditafsirkan. Dari penjelasan tersebut akan terlihat kaitan erat dengan ideologi yang dibawa, karena proses penyampaian tersebut tidak murni mengenai teknis jurnalistik semata, tetapi juga ada politik pemberitaan. ${ }^{14}$

\section{Konsep Poligami}

\footnotetext{
14 Eriyanto, Analisis Wacana (Yogyakarta: LKiS Yogyakarta, 2001), 210-211.
} 


\section{Definisi Poligami}

Secara etimologis, istilah poligami memiliki pergeseran makna dari arti bahasa. Jika merujuk pada etimologisnya, poligami berasal dari bahasa Yunani, yakni dari kata apolus (banyak) dan gamos (perkawinan). ${ }^{15}$ Menurut Kamus Besar Bahasa Indonesia, istilah poligami memiliki makna sebagai sistem perkawinan yang salah satu pihak memiliki atau mengawini beberapa lawan jenisnya dalam waktu yang bersamaan. Sehingga poligami adalah perkawinan yang banyak atau perkawinan dengan beberapa lawan jenisnya. Hal ini bisa pihak laki-laki menikahi banyak wanita atau sebaliknya. Jika merujuk pada realitas seorang laki-laki memiliki banyak wanita maka secara etimologis adalah poligini. Namun di masyarakat ada pergeseran makna, bahwa poligami merujuk kepada seorang laki-laki yang memiliki banyak istri (lebih dari satu).

\section{Dasar Hukum Poligami}

Pernikahan poligami tidak semata-mata karena latah atau kebudayaan bangsa/negara Islam, namun karena ada landasan hukum agama Islam yang dijadikan pedoman bahwa Islam membolehkan seorang laki-laki memiliki lebih dari satu istri. Argumentasi agama yang bisa digunakan oleh yang pro poligami adalah surah Annisa ayat 3, dan diambil hanya sepenggal yaitu boleh menikahi perempuan dua, tiga, empat asal bisa berlaku adil. ${ }^{16}$ Kebolehan poligami bersifat kontekstual, darurat dan memiliki persyaratan yang ketat. Adapun yang dimaksud kontekstual adalah sesuai dengan Alquran surah Annisa ayat 3, disebutkan poligami harus

${ }^{15}$ Fathonah, "Telaah Poligami.," 14-15.

16 Siti Hikmah, "Fakta Poligami Sebagai Bentuk Kekerasan Terhadap Perempuan," Jurnal SAWWA, Vol. 7 No. 2 (April 2012): 7. menyesuaikan dengan kondisi sosiologis masyarakat sekitar. Berkaitan persyaratan adalah mengenai kesanggupan suami berlaku adil terhadap istri dan anak-anak mereka, namun jika suami takut tidak sanggup berlaku adil maka tidak boleh melakukan poligami. ${ }^{17}$

Dalam surah Annisa ayat 3 di dalam buku Women in Islamic Shari'ah menyelaskan bahwa ayat ini diturunkan setelah terjadi perang Uhud. Dalam buku tersebut diceritakan ada tujuh puluh orang muslim yang meninggal syahid. Tiba-tiba tujuh puluh rumah di Madinah kehilangan anggota keluarga laki-lakinya dan memunculkan pertanyaan bagaimana mengurus semua janda-janda dan anakanak yatim tersebut. Buku tersebut menjelaskan bahwa surah Annisa ayat 3 turun sebagaimana diuraikan oleh Aisyah r.a. (istri Nabi) menyangkut sikap sementara orang yang ingin mengawini anak-anak yatim yang kaya dan cantik dan berada dalam pemeliharannya, tetapi tidak ingin memberinya mas kawin yang sesuai, serta tidak memperlakukannya secara adil. Ayat ini melarang hal tersebut dengan satu kalimat yang sangat tegas. Penyebutan dua, tiga, atau empat pada hakikatnya adalah dalam rangka tuntutan adil kepada mereka. Redaksi ayat ini mirip dengan ucapan seseorang yang melarang orang lain untuk memakan makanan tertentu dan untuk menguatkan larangannya itu dikatakannya, "Jika Anda khawatir akan sakit bila makan makanan ini, maka habiskan saja makanan selainnya yang ada di hadapan Anda selama Anda tidak khawatir sakit." Perintah

\footnotetext{
17 Sunaryo, “Poligami di Indonesia.," 145.
} 
menghabiskan makanan yang lain tidak lain hanya untuk menekankan larangan memakan makanan tertentu itu. ${ }^{18}$

Diperbolehkannya poligami dalam konsep fikih juga bisa dikarenakan sebab umum maupun khusus. Sebab umum seperti jumlah laki-laki lebih sedikit dari perempuan atau fenomena angka kelahiran perempuan yang banyak. Sebab khusus yang dimaksudkan adalah ketidakhadiran anak dalam perkawinan tersebut, sakitnya istri atau dorongan nafsu suami yang terlalu besar dan tidak mampu dilayani oleh satu istri secara biologis. ${ }^{19}$ Sejarah Nabi Muhammad sering dijadikan pijakan oleh beberapa orang untuk melegitimasi praktik poligami. Namun jika melihat sejarah Nabi tidak berpoligami ketika menikah dengan Khadijah r.a. ${ }^{20} \mathrm{Hal}$ ini bisa bermakna bahwa perilaku poligami Nabi tidak muncul sejak awal pernikahannya, namun baru muncul ketika Khadijah wafat. Berikutnya juga mengenai wanita yang dinikahi oleh Nabi setelah kematian Khadijah adalah janda, kecuali Aisyah. ${ }^{21}$ Sejarah ini menunjukkan bahwa Nabi memiliki kesetiaan dalam pernikahannya dengan Khadijah, dan ketika melakukan poligami juga wanita janda, sehingga Nabi tidak memilih wanita-wanita yang masih muda dan belum menikah, kecuali Aisyah.

\section{Analisis Wacana Sara Mills}

\footnotetext{
18 Mochammad Fathoni, "Respon Pelaku Poligami di Kabupaten Kediri Prop. Jawa Timur Terhadap Pelaksanaan Poligami Dalam Perspektif Hukum Islam dan Hukum Positif," (Tesis dari UIN Sunan Ampel, 2009), 28
}

Dalam model analisisnya, Sara Mills membahas bagaimana komunikator menyajikan aktor-aktor yang ditampilkan dalam teks. Posisi ini adalah siapa yang akan ditampilkan dalam teks. Siapa yang akan menjadi subjek dan objek penceritaan akan memengaruhi bentuk ataupun struktur teks yang disampaikan. Selain itu, Sara Mills juga memusatkan perhatian pada bagaimana pembaca dan penulis ditampilkan dalam teks. Serta bagaimana pembaca mengidentifikasikan dan menempatkan dirinya dalam penceritaan teks. Dari pemosisian ini akan ditempatkan dan ditampilkan bahwa satu pihak menjadi legitimate dan pihak lain menjadi illegitimate. $^{22}$

Kerangka analisis Sara Mills memiliki fokus pada dua aspek, yakni posisi subjek-objek dan juga posisi penulis-pembaca. Secara konsep analisis Sara Mills sendiri berdasarkan media teks berupa novel atau karangan. Dalam konteks penelitian ini ada penyesuaian konteks kerangka dalam analisis yang akan dilakukan. Dalam penelitian ini istilah penulis adalah penceramah, hal ini didasarkan pada penggunaan kerangka analisis Sara Mills tidak hanya berhenti pada novel atau karangan namun juga bisa dalam media gambar atau foto dan juga berita. ${ }^{23}$ Untuk istilah pembaca akan dikontekskan pada penonton yang mendengarkan ceramah tersebut. Proses analisis ceramah Mamah Dedeh dilakukan dengan melakukan penyajian dalam bentuk teks yang hal ini

\footnotetext{
${ }^{19}$ Atik Wartini, “Poligami: Dari Figh hingga PerundangUndangan," Hunafa: Jurnal Studia Islamika, Vol 10 No. 2 (Desember 2013): 249-250.

20 Ibid., 255.

21 Ibid., 257.

22 Eriyanto, Analisis Wacana., 200.

${ }^{23}$ Ibid., 199.
} 
menjadi kesamaan dan juga kesesuaian dengan kerangka analisis Sara Mills berupa teks. Dalam tabel 1 akan dijelaskan secara umum gambaran kerangka analisis Sara Mills.

Tabel 1 - Kerangka Analisis Sara Mills

\begin{tabular}{|c|c|}
\hline Tingkat & Yang ingin dilihat \\
\hline $\begin{array}{c}\text { Posisi } \\
\text { subjek- } \\
\text { objek }\end{array}$ & $\begin{array}{l}\text { Bagaimana peristiwa dilihat, } \\
\text { dari kecamata siapa peristiwa } \\
\text { itu dilihat. Siapa yang } \\
\text { diposisikan sebagai pencerita } \\
\text { (subjek) dan siapa yang } \\
\text { menjadi objek yang } \\
\text { diceritakan. Apakah masing- } \\
\text { masing aktor dan kelompok } \\
\text { sosial mempunyai } \\
\text { kesempatan untuk } \\
\text { menampilkan dirinya sendiri, } \\
\text { gagasannya atau } \\
\text { kehadirannya, atau } \\
\text { gagasannya ditampilkan oleh } \\
\text { kelompok/orang lain }\end{array}$ \\
\hline $\begin{array}{c}\text { Posisi } \\
\text { pembicara } \\
\text {-penonton }\end{array}$ & $\begin{array}{l}\text { Bagaimana posisi penonton } \\
\text { ditampilkan dalam teks. } \\
\text { Bagaimana penonton } \\
\text { memosisikan dirinya dalam } \\
\text { teks yang ditampilkan. Kepada } \\
\text { kelompok manakah penonton } \\
\text { mengidentifikasi dirinya }\end{array}$ \\
\hline
\end{tabular}

\section{Metodologi}

Pendekatan yang digunakan dalam studi ini adalah kualitatif. Dalam pengumpulan data menggunakan dokumentasi video ceramah Mamah Dedeh tanggal 8 oktober 2015. Berdasarkan video ceramah tersebut akan akan dibuat transkrip ke dalam bentuk teks yang menjadi bahan untuk analisis wacana ceramah. Metode analisis data berdasarkan Miles and Huberman terdiri dari tiga tahap yakni reduksi data, data display, dan conclusion drawing/verification. ${ }^{24}$ Reduksi data dalam ceramah menyampaikan data ceramah sesi satu dan dua yang sesuai dengan fokus pembahasan poligami, hal ini karena dalam sesi tanya jawab ada yang pertanyaan kurang berhubungan dengan poligami. Penyajian data dalam ceramah akan disajikan dalam bentuk transkrip. Sedangkan untuk kesimpulannya berdasarkan konteks video pada tanggal 8 oktober 2015 saja, jika ada ceramahceramah lain Mamah Dedeh yang memperdalam atau membahas lagi maka bisa menjadi koreksi. Dalam studi ini, akan dijabarkan terlebih dahulu proses ceramah yang dilakukan oleh Mamah Dedeh yang kemudian akan dilanjutkan dengan analisis ceramah yang disampaikan Mamah Dedeh dengan teori analisis wacana Sara Mills. Adapun alur analisis studi ini adalah sebagai berikut:

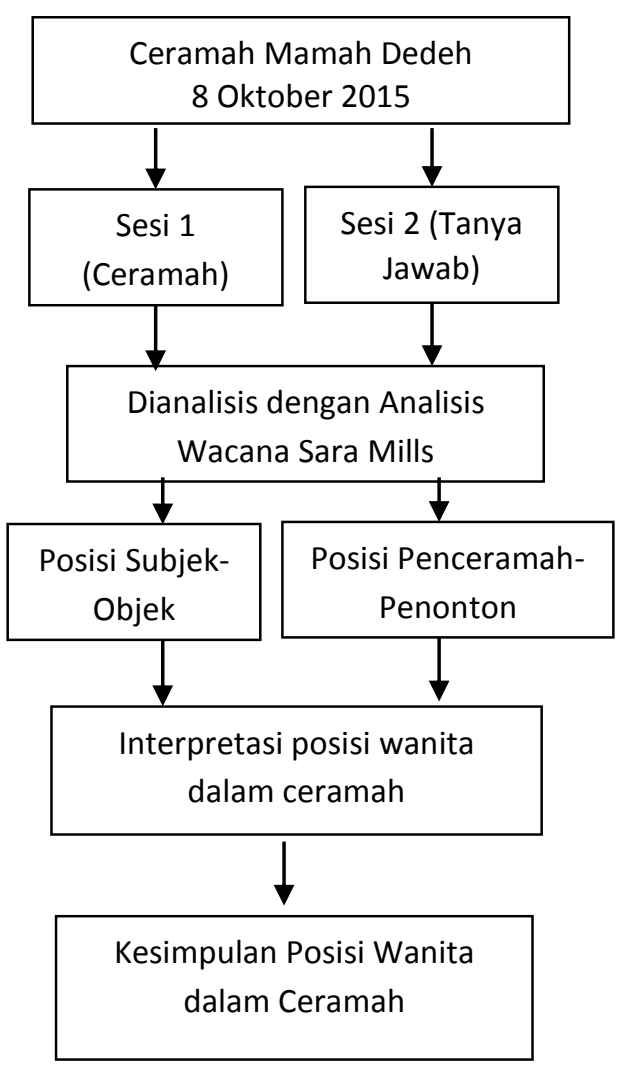

24 Sugiyono, Metode Penelitian Kuantitatif Kualitatif dan R\&D (Bandung: Alfabeta, 2012), 246. 
Gambar 1 - Skesta Alur Analisis Studi

\section{Ceramah Mamah Dedeh}

Dalam ceramah Mamah Dedeh menggunakan dua sesi, yaitu, pertama, Mamah Dedeh menjelaskan terlebih dahulu selama kurang lebih sepuluh menit mengenai pembahasan tema pada ceramah "Poligami Bisakah Adil." Dalam sesi ini Mamah Dedeh tidak menerima atau belum membuka pertanyaan dari para penonton, hanya berceramah secara satu arah. Mamah Dedeh menyampaikan isi ceramahnya, sedangkan para penonton mendengarkan dan belum diperkenankan mengajukan pertanyaan. Kedua, Mamah Dedeh melanjutkan dengan membuka sesi tanya jawab (interaksi) dengan penonton yang ada di studio atau di rumah baik melalui telepon maupun video call. Mayoritas penonton yang ada di studio adalah kaum perempuan. Pada sesi kedua ini, Mamah Dedeh menyediakan waktu yang lebih lama daripada sesi pertama, pada sesi kedua ini durasi yang tersedia adalah kurang lebih tiga puluh menit.

\section{Sesi Ceramah}

Berikut transkrip data sesi ceramah Mamah Dedeh:

"Poligami bisakah adil. Anda silahkan lihat dalam surat Annisa ayat 3, fangkihu ma taba lakum minan-nisa'i masna wa sulasa wa ruba, fa in khiftum alla ta'dilu fa wahidatan. Nikahilah perempuan yang kamu sukai boleh dua, boleh tiga, boleh empat baru koma kalau kamu takut tidak berbuat adil cukup satu. Adilnya dimana,

\footnotetext{
${ }^{25}$ Mama Dedeh, "Poligami Bisakah Adil?" Mamah dan
} Aa Beraksi, Edisi 8 Oktober 2015, Menit 02:04-03.20. adil papan, adil pangan, adil waktu, adil cinta" ${ }^{25}$

"Adil papan, kalau Anda punya istri dua, tiga atau empat, bikinkan rumah yang nilainya hampir sama. Yang dua pangan, biaya hidup mereka harus sesuai kebutuhan mereka sesuai kemampuan para suami. Misalnya istri yang pertama anaknya sudah SMA, 3 anaknya, kasihlah duit sepuluh juta per bulan. Istri yang kedua anaknya masih SMP, cuman dua, kasilah tujuh juta per bulan. Istri yang ketika anaknya baru satu, SD, kasilah lima juta sebulan. Istri yang keempat baru nikah kasilah dua juta setengah sebulan. Jadi yang namanya adil bukan jumlah nominalnya yang sama, tapi sesuai dengan kebutuhan yang harus mereka keluarkan." 26

"Sekarang adil waktu, kalau Anda bermalam di istri yang pertama dua malam, istri yang kedua dua malam, istri yang ketiga dua malam, istri yang keempat dua malam. Biasanya suami kalau baru menikah dengan istri yang muda lebih lama di sana."27

"Dan kamu sekali-kali tidak akan dapat berlaku adil di antara istri-istri kamu, walaupun kamu sangat ingin berbuat demikian. Namun kamu jangan cenderung kepada salah satu di antara mereka dan mengatung-katungkan yang lain. Artinya walaupun Anda seorang suami, Anda di antara 3 (tiga) atau 4 (empat) istri Anda yang lebih Anda cintai, silahkan, namun jangan nampak di hadapan istri yang lain."

"Rasul pun bersabda, 'Seandainya ada seorang laki-laki punya istri 2 (dua) atau 3 (tiga), dia cenderung mencintai melebihkan salah satu daripada yang lain, begitu meninggal dunia saat yaumul akhir kondisinya miring ke sebelah.' Hadis ini, saya tidak main-main."

"Hadis lain, Rasul mengatakan, kalau seandainya seorang laki-laki memiliki istri dua, tiga atau empat, dia tidak berlaku adil

26 Ibid., Menit 03:23-04:32.

27 Ibid., Menit 04:33-04:48 dan 05:07-05:14. 
dalam masalah papan, pangan, dan waktu maka dia akan stroke sebelah." "Tiga golongan manusia yang jangankan sudah mati, hidup pun diazab oleh Allah. Satu, seseorang yang menyakiti orang tua dan mertua. Dua, orang yang menyakiti pasangan, suami yang menyakiti istri, istri yang menyakiti suami. Tiga, orang yang mengambil hak orang lain, mencuri, korupsi, nipu orang, dia mengambil hak orang atau ngambil warisan saudaranya. Rasul mengatakan jangan kan sudah mati hidup pun diazab oleh Allah."

\section{Sesi Tanya Jawab}

Berikut transkrip data sesi tanya jawab dalam ceramah Mamah Dedeh:

Pertanyaan 1: "Curhat dong Ma, Ma mau nanya kok yang poligami itu kebanyakan kiai-kiai gitu sama orang kaya?" Jawaban Mamah Dedeh: "Lah iyalah, orang miskin bagaimana dia poligami, bini satu aja dia kagak umpanin. Kenapa banyak para kiai, para pejabat yang poligami. Kiai itu duitnya banyak bu, barokah. Pejabat duitnya banyak, insentif ada, tunjangannnya ada, kanan kirinya depan belakang. Lha iyalah bini mereka dua, dimakan bini satu kagak abis. Jangan pake kenapa, orang susah, orang kere, gimana bini dua, bini satu aja terlunta-lunta" 28

Pertanyaan 2: "curhat dong Ma, begini Ma, kalau ada suami kawin lagi tanpa sepengetahuan istri yang pertama, nikah siri?" Jawaban Mamah Dedeh: "Ibu Ade dan pemirsa, dalam hukum Islam tidak ada kewajiban suami kawin lagi pake ijin ke istri yang pertama. Tapi Undang-Undang negara kita, PP 10 menyatakan kalau kaum laki-laki wajib hukumnya ada surat ijin tertulis dari tangan istri pertama. Jadi dalam Islam tidak masalah, asal bisa berbuat adil"29

Pertanyaan 3: "Curhat dong Ma, saya baru menikah usianya masih tiga bulan, dan

28 Ibid., Menit 10:40-12:16.

29 Ibid., Menit 14:45-16:15. misal saya mengijinkan suami saya keluar menemui wanita lain apa secara tidak langsung saya mengijinkan dia untuk selingkuh?" Jawaban Mamah Dedeh: "Jika kembali kepada pertanyaan, kalau ada lakilaki mau menikah lagi, istrinya mengijinkan, kembali kepada Anda, relakah Anda, maukah Anda di madu. Kalau Anda minum madu semua penyakit hilang, kalau Anda dimadu, semua penyakit bisa datang. Jadi kalau Anda mengijinkan suami Anda menikah lagi silahkan, tapi Anda jangan munafik. Benarkah dari hati, atau mulut mengatakan boleh nikah namun sakitnya di sini. Kita sebagai perempuan punya hak memilih, mau maju atau mundur. Tujuan pernikahan adalah untuk ketenangan batin kita" ${ }^{\prime \prime 30}$

Pertanyaan 4: "Katanya ada seorang suami yang dipaksa menikah lagi oleh istrinya karena istrinya tidak bisa memberikan keturunan, suaminya gak mau, itu gimana itu Ma?" Jawaban Mamah Dedeh: "Jika Anda sebagai suami jangan mau menikah lagi. Anda lihat punya anak, gak punya anak, itu bukan hak kita, itu hak prerogatif Allah. Anda lihat pada surah Asysyura ayat 49-50. Allah berfirman, 'Akulah yang memberikan anak perempuan kepada siapa yang aku kehendaki. Akulah yang memberikan anak laki-laki kepada siapa yang aku kehendaki. Akulah yang memberikan anak laki-laki dan perempuan kepada siapa yang aku kehendaki. Akulah yang menjadikan seseorang mandul.' Sangat jelas bahwa surat ini mengatakan bahwa ketika ada sebuah keluarga memiliki anak cewek semua, itu kehendak Allah. Kalau ada keluarga semua anak cowok, itu kehendak Allah. Kalau ada keluarga anak cowok cewek itu kehendak Allah. Kalau ada orang yang mandul juga kehendak Allah. Istrinya bilang 'bang kawin lagi biar punya anak', siapa tahu lakinya yang mandul. Cuma selama ini maaf tanda kutip selama ini kebanyakan laki-laki tidak mau

30 Ibid., Menit 17:22-20:50. 
dipersalahkan, perempuan dipersalahkan. Mikir, periksa ke dokter dua-duanya jangan Anda cuek. Terbukti ketika mereka ribut dan bercerai, yang laki-laki kawin lagi, yang perempuan kawin lagi. Eh yang perempuan punya anak yang laki-laki kagak. Jangan nyalahin perempuan terus ${ }^{\prime \prime 31}$

Pertanyaan 5: "curhat dong Ma, saya pernah mendengar mengenai poligami itu sunah, apakah itu betul, Ma?" Jawaban Mamah Dedeh: "Tidak, yang namanya sunah Rasul bukan cuma nikah lagi, urusin fakir miskin, urusin anak yatim, berdakwah yang benar, banyak bersedekah, banyak ibadah. Sunah Rasul perkataan Nabi, perbuatan Nabi, takrir Nabi, keinginan Nabi, itu sunah Rasul. Banyak kaum laki-laki yang salah mengartikan. 'kita mah ngerjain sunah Nabi, kawin lagi', artinya laki-laki yang ngomong begitu otaknya 'ngeres'. Bukan ngikuti sunah Rasul, itu mah kegedean birahinya. Rasul menikah dengan Ummu Salamah yang sudah tua anaknya banyak orang miskin. Apakah kalian laki-laki mau menikah dengan nenek-nenek? Kebanyakan sekarang ngomong sunah Rasul tapi yang dinikahi yang montok, yang bohai. Itu mah bukan sunah Rasul, itu mah nafsu"32

Pertanyaan 6: "Buat yang sudah dipoligami Ma, bagaimana supaya bisa ikhlas?" Jawaban Mamah Dedeh: "Saya yakin siapapun kita, jarang sekali walaupun ada, perempuan yang mau dipoligami. Sekarang, apa sih kewajiban kita terhadap suami: jangan meninggalkan tempat tidur suami, jangan menyembunyikan hak suami di tubuh kita, taat kepada perintah suami selama sesuai aturan agama, jangan keluar rumah tanpa ijin suami, jangan masukkan orang ke rumah terlebih yang tidak disukai suami. Jika semua sudah kita lakukan dengan baik, suami kawin lagi, mungkin

\footnotetext{
31 Ibid., Menit 21:25-23:10.

32 Ibid., Menit 24:00-25:40.

33 Ibid., Menit 34:22-36:30.
}

takdir kita. Silakan Anda lihat Attagabun ayat 11. Musibah yang menimpa diri kalian, semua diijinkan oleh Allah. Siapa yang beriman kepada Allah, hatinya diberikan petunjuk dan Allah mencatat segala yang kalian kerjakan. Jadi itu atas ijin Allah. Makanya itu harus diterima dengan iman, mungkin sudah takdir saya. Rukun iman ada berapa? Rukun iman ke enam apa? Percaya kepada qodo' dan qadarnya Allah. Gak apaapa, jadi pola pikirnya dirubah. Alhamdullilah yang tiga hari di sini, empat hari di sana. Saya cucian ringan, masak juga gak berat-berat terlalu, masya Allah bisa ngaji, belajar agama, lari ke hal yang positif. Insyallah hidup kita barokah" ${ }^{\prime \prime 3}$

\section{Profil Mamah Dedeh}

Untuk semakin memperkuat dugaan posisi perempuan terhadap poligami, maka membutuhkan asumsi kondisi Mamah Dedeh sebagai penceramah untuk menunjukkan latar belakang kehidupan yang bisa jadi menjadi pijakan dalam menjawab pertanyaan saat sesi ceramah. Berikut data yang mengenai profil Mamah Dedeh yang dikutip langsung lewat pengakuan Mamah Dedeh sendiri tentang profil dirinya.

"Lulus SD, aku bersekolah di Pendidikan Guru Agama (PGA) selama enam tahun. mungkin memang sudah jadi jalan hidupku untuk selalu berada di dunia keagamaan. Lagi pula, kedua orang tuaku sejak dulu juga berdakwah, dan sejak kecil anak-anaknya terbiasa mengajar mengaji dan ceramah. Karena itu pula, kami mendapat julukan anak bedug, karena mengaji kan identik dengan masjid. Aku mendalami ilmu agama di IAIN yang kini bernama UIN Syarief Hidayatullah di Ciputat" ${ }^{\prime 34}$

\footnotetext{
${ }^{34}$ Hasuna Daylailatu, "Mamah Dedeh (2): Anak Bedug Jadi Istri Anak Kiai", Situs Tabloidnova.com, 24 September 2009
} 
"Lagi pula, kedua orang tuaku sejak dulu juga berdakwah, dan sejak kecil anakanaknya terbiasa mengajar mengaji dan ceramah. Setelah menikah selain berdakwah di Ciputat, aku juga mengajar mengaji di Tanah Abang, mengikuti kegiatan keluarga suami. Setelah pindah ke Depok, semakin luas pergaulanku, dan makin banyak tempatku berdakwah. ${ }^{\prime 35}$

"Berkebalikan dengan kedua orang tuaku dulu, keempat anakku semuanya laki-laki, kecuali anak keduaku yang perempuan. Dalam mendidik anak, aku tidak bisa meniru kedua orang tuaku secara persis. Apalagi, aku dan suami tidak memiliki empang. Soal disiplin, aku juga tidak bisa terlalu ketat seperti kedua orang tuaku dulu, karena zaman sudah berubah. Namun, aku bersyukur kami berhasil mendidik anakanakku dengan baik. Sekarang, semua anakku tinggal di Depok, kecuali anak ketiga yang tinggal di Ciamis untuk meneruskan usaha orang tuaku. ${ }^{136}$

Biodata tersebut menunjukkan bahwa Mamah Dedeh besar dalam keluarga seorang pendakwah yang memiliki dasar pendidikan agama. Hal tersebut memungkinkan menjadi dasar dan pandangannya dalam memahami poligami. Dalam sejarah kehidupannya, Mamah Dedeh selalu mengikuti kemanapun suaminya pergi. Hal tersebut menunjukkan memang Mamah Dedeh dibesarkan dan hidup di lingkungan yang seorang istri menurut kepada suaminya, dan ikut ke mana pun suaminya pergi. Dari penjelasan tersebut mengindikasikan bahwa Mamah Dedeh memiliki pandangan seorang wanita mungkin akan lebih baik dan mungkin harus menuruti perintah suami atau bisa dikatakan bahwa seorang istri harus

http://tabloidnova.com/Selebriti/Profil/MamahDedeh-2-Anak-Bedug-Jadi-Istri-Anak-Kiai menurut kepada suaminya. Suami dianggap sebagai seorang imam yang harus diikuti dan dituruti. Maka tidak heran jika posisi perempuan dalam ceramah poligami juga menunjukkan bahwa perempuan pada akhirnya harus menurut dan bersabar serta ikhlas ketika suaminya berpoligami. Karena istri berkewajiban untuk melayani suami, yang dalam konteks ini adalah rela untuk dipoligami

\section{Analisis Wacana Ceramah Mamah Dedeh}

\section{Analisis Mengenai Posisi Subjek Dan} Objek

Pada sesi satu, dengan menggunakan penyataan harus adil dalam papan, pangan, waktu dan cinta menunjukkan bahwa dalam penyampaian ini subjek yang menceritakan adalah kaum laki-laki. Hal ini diperkuat dengan penyataan selanjutnya yang menjelaskan bahwa jika seorang berpoligami maka boleh mencintai salah satu dari tiga atau empat istrinya walaupun tidak boleh ketahuan oleh istri yang lain. Penjelasan mengenai hadis Rasul yang menyatakan bahwa seorang laki-laki memiliki dua sampai empat istri harus bisa adil, juga menunjukkan bahwa subjek yang menceritakan di sini adalah kaum laki-laki. Hal ini menunjukkan bahwa laki-laki selama bisa berbuat adil maka diperbolehkan melakukan poligami. Penyampaian ini seolah-olah menunjukkan bahwa syarat berpoligami hanyalah masalah keadilan saja. Objek yang diceritakan adalah kaum perempuan. Perempuan tidak diberikan ruang untuk menunjukkan atau diwakilkan pendapatnya mengenai praktik poligami.

\footnotetext{
${ }^{35}$ Ibid.

${ }^{36}$ Ibid.
} 
Sebab yang menjadi fokus pencerita adalah kemampuan keadilan untuk istri-istri lainnya. Maka secara tidak langsung kaum perempuan dalam konteks ini hanya menjadi objek yang diceritakan.

Pada sesi dua, diawali dengan pertanyaan mengenai poligami dilakukan oleh orangorang kaya, menunjukkan yang menjadi subjek adalah kaum laki-laki. Kaum laki-laki dianggap bisa poligami karena memang memiliki kemampuan ekonomi untuk membiayai lebih dari satu istri hal ini diketahui dalam ceramahnya "hartanya untuk satu istri tidak habis." Dalam pernyataan ini menunjukkan bahwa kaum perempuan menjadi objek yang diceritakan dan perempuan tidak memiliki akses dan pendapat mengenai kondisi tersebut. Perempuan secara tidak langsung harus menerima jika suaminya memiliki ekonomi berlebih dan memutuskan untuk berpoligami.

Kemudian pertanyaan mengenai ijin suami kepada istri jika mau poligami, dalam pernyataan tersebut yang menjadi subjek adalah kaum laki-laki. Hal ini ditunjukkan dengan pendapat yang mengatakan bahwa dalam Islam tidak ada kewajiban untuk lapor kepada istri sebelumnya. Sehingga tanpa ijin atau restu istri sebelumnya pun, kaum lakilaki masih punya hak untuk menikah lagi. Maka objek yang dijadikan bahan cerita di sini adalah kaum perempuan. Untuk kesekian kalinya kaum perempuan tidak banyak menjelaskan bagaimana pendapat mereka terhadap perijinan tersebut. Sekali lagi kaum perempuan menjadi objek yang tidak memiliki ruang untuk memberikan pendapat.
Masuk ke pertanyaan ketiga sampai kelima, mulai dari ijin istri terhadap suami yang ingin poligami, kemudian mengenai poligami disebabkan karena tidak mampu memberikan keturunan serta mengenai poligami sunah Rasul. Untuk tiga pernyataan ini, subjek yang menjadi pencerita adalah kaum perempuan. Hal ini karena menunjukkan bagaimana perasaan kaum perempuan ketika menghadapi hal tersebut. Untuk masalah ijin, dalam pernyataan itu menunjukkan bahwa kaum perempuan akan bisa sakit jika dipoligami, akan muncul perasaan tidak nyaman dan memberikan gambaran untuk perempuan agar menentukan sikapnya apakah mau melanjutkan pernikahan atau tidak.

Untuk pertanyaan mengenai keturunan menjadi sebab poligami juga menunjukkan subjek adalah perempuan. Dalam pernyataan itu dijelaskan bahwa perempuan harus memberikan perlawanan jika suami menikah lagi karena dugaan mandul terhadap istri. Hal ini menunjukkan bahwa perempuan harus melakukan uji kesehatan untuk menunjukkan siapa yang bermasalah terhadap keturunan tersebut. Terakhir mengenai poligami adalah sunah Rasul, dalam penyataan itu menunjukkan bahwa perempuan menjadi korban dalam poligami. Pernyataan itu menunjukkan sanggahan kepada kaum laki-laki mengenai praktik poligami zaman sekarang dengan yang pernah dilakukan oleh Nabi. Semua perilaku poligami sudah tidak sesuai lagi. Ketiga pertanyaan tersebut sekaligus juga menjadikan laki-laki sebagai objek yang diceritakan, karena laki-laki pada tiga pertanyaan ini tidak memberikan pendapat atau tidak terlihat argumentasi yang diberikan sebagai pembanding. Hal tersebut menunjukkan Mamah Dedeh juga masih 
menjadikan perempuan sebagai subjek ceramahnya.

Namun pada pertanyaan terakhir yang membahas mengenai keikhlasan, Mamah Dedeh kembali kepada laki-laki sebagai subjek dan perempuan sebagai objek. Hal tersebut dibuktikan dengan mengawali jawaban dengan menunjukkan tugas istri terhadap suami, kemudian ditunjang dengan surah Attagabun untuk mengikhlaskan jika dipoligami dan menganggap itu adalah takdir Allah dan tugas perempuan untuk menerima hal itu. Hal ini menunjukkan bahwa laki-laki sebagai subjek merasa bahwa harusnya perempuan yang melakukan evaluasi dan patuh terhadap suami, karena dalam pernyataan itu tidak ditunjukkan pula kewajiban suami terhadap istri. Kesan seolah kewajiban istri terhadap suami lebih penting daripada kewajiban suami terhadap istri. Padahal jika kembali pada sesi satu, Mamah Dedeh sempat menjelaskan bahwa salah satu golongan yang tidak disukai Allah adalah yang melukai pasangan, baik suami terhadap istri atau sebaliknya. Namun dalam pernyataan ini hanya ditunjukkan bahwa istri yang harus tunduk dan patuh terhadap suami. Maka terlihat bahwa perempuan tidak memiliki pendapat atau argumen dalam konteks ini karena asumsi jawaban disampaikan dalam perspektif lakilaki. Kaum perempuan cenderung diposisikan harus tunduk kepada seorang suami walaupun itu mengenai poligami. Terkesan bahwa seorang istri tidak memiliki kuasa untuk memutuskan bagaimana dia harus bersikap jika di poligami oleh suaminya.

\section{Analisis Mengenai Posisi Penceramah dan Penonton}

Pada sesi satu, posisi penceramah dan penonton berada pada sudut pandang lakilaki. Hal ini ditunjukkan dengan pendetailan syarat keadilan yang harus dipenuhi seorang suami untuk bisa berpoligami. Dalam hal ini penonton diajak untuk memahami dan mewajari jika ada seorang suami yang berpoligami lagi dimungkinkan karena dia memiliki kemampuan untuk berbuat adil terhadap istri-istrinya. Dan banyak standar yang ditampilkan cenderung pada kemampuan ekonomi, seperti kemampuan memenuhi kebutuhan papan dan pangan. Dalam wacana tersebut, Mamah Dedeh berpendapat bahwa selama laki-laki memiliki kemampuan ekonomi guna menjamin pangan dan papan istri-istri yang lain, maka laki-laki diperbolehkan untuk menikah lagi.

Pada sesi dua terdapat dua gambaran, yakni saat Mamah Dedeh memosisikan penceramah dan penonton kepada kaum laki-laki dan perempuan. Untuk pemosisian kaum laki-laki ditunjukkan pada pertanyaan satu, dua, dan enam. Sedangkan untuk kaum perempuan ditunjukkan pada pertanyaan tiga, empat dan lima. Bukti posisi penceramah dan penonton berada pada sudut pandang laki-laki adalah dalam penyataan mengenai yang menikah lagi kebanyakan kaum kaya, Mamah Dedeh menjelaskan bahwa hal itu sangat wajar karena uangnya banyak sehingga bisa untuk membiayai istri-istrinya. Dalam pernyataan ini, Mamah Dedeh mengajak penonton untuk mewajari dan memaklumi orangorang kaya yang menikah lagi. Laki-laki kaya dianggap wajar berpoligami karena mereka memiliki kemampuan ekonomi. Pernyataan ini sekaligus pula menegaskan bahwa syarat untuk berpoligami adalah kemampuan ekonomi. Otomatis pada aspek ini, kaum 
perempuan ditempatkan harus bersedia/menerima kondisi itu.

Berikutnya pada pernyataan mengenai ijin menikah, dari jawaban Mamah Dedeh diketahui bahwa laki-laki dalam berpoligami tidak perlu ijin kepada istri dengan dasar syariat agama Islam. Perempuan yang menolak atau tidak mengijinkan akan dianggap tidak sesuai syar'i, dan dianggap aneh, karena secara hukum Islam tidak ada keharusan ijin. Walaupun juga dijelaskan bahwa dalam hukum negara Indonesia mengharuskan adanya ijin tertulis.

Saat menjelaskan mengenai keikhlasan istri jika dipoligami pada pernyataan keenam. Dalam pernyataan itu penonton diajak untuk memahami kewajiban seorang perempuan kepada suaminya. Hal itu menunjukkan bahwa perempuan harus menuruti dan melayani suaminya walaupun dirinya dipoligami. Ditambah penonton disajikan pendasaran ayat yang menunjukkan bahwa ada istilah takdir. Seolah-olah wanita tidak punya kuasa untuk melawan atau bahkan menolak hal tersebut jika sudah mendapati suaminya menikah lagi. Dari sini terlihat bahwa arah Mamah Dedeh adalah mengajak penonton untuk berempati dan mewajari jika ada seorang suami yang menikah lagi.

Pada penggambaran dari sudut pandang perempuan juga dilakukan oleh Mamah Dedeh, hal itu ditunjukkan dengan pernyataan mengenai ijin istri kepada suami yang poligami. Pada kesempatan itu menunjukkan bahwa bagaimana perasaan dan kondisi sebenarnya dari poligami dari sudut pandang perempuan, perempuan akan menjadi sakit karena dimadu bukan malah sehat. Hal-hal ini mengindikasikan bahwa penonton harusnya juga memiliki pemahaman yang sama dengan yang Mamah Dedeh sampaikan, yaitu memahami kondisi perempuan jika dipoligami yang tersiksa dan kecenderungan tidak memiliki kemampuan utnuk mengatakan tidak kepada suaminya. Selain itu Mamah Dedeh juga menunjukkan dengan memberikan pernyataan mengenai kesehatan seorang istri yang dipoligami karena tidak memiliki keturunan. Dalam konteks itu penonton diajak untuk mengetahui cara pandang dari sudut pandang seorang perempuan yang memiliki kemampuan untuk melawan atau bahkan menolak poligami dengan alasan masalah keturunan.

Terakhir, Mamah Dedeh menjelaskan mengenai sunah Rasul. Mamah Dedeh menyatakan bahwa perilaku poligami saat ini sudah tidak sesuai dengan sunah Rasul, karena yang dinikahi adalah perempuan yang lebih muda dan lebih menarik secara fisik. Hal ini bertentangan dengan poligami yang dilakukan Rasul. Arah dari penyataan ini adalah mengajak penonton untuk memiliki penilaian yang sama yakni laki-laki yang ingin poligami itu adalah orang yang memiliki nafsu terlalu besar. Hal ini menunjukkan Mamah Dedeh berada atau memosisikan sebagai seorang perempuan.

Dari penjelasan di atas menunjukkan dari awal ceramah tidak ada statement tegas yang mengatakan bahwa poligami dilarang. Mamah Dedeh hanya menekankan aspek keadilan saat poligami. Hal ini menunjukkan bahwa ada gambaran bahwa poligami tidak masalah dilakukan. Kemudian ketika memasuki sesi tanya jawab terlihat bahwa Mamah Dedeh berusaha menjelaskan berdasarkan perspektif perempuan dan lakilaki. Namun tetap sekali lagi pada sesi tanya 
jawab ini tidak ada sanggahan mengenai masalah poligami dilarang bagi kaum lakilaki untuk zaman sekarang. Dalam penjelasannya beberapa kali menunjukkan dukungan terhadap kaum perempuan, namun di sisi lain juga menunjukkan bahwa perempuan juga harus rela dan ikhlas ketika dipoligami.

Pembahasan mengenai masalah ekonomi, sunah Rasul bisa menjadi alat untuk melarang poligami, namun dalam penjelasannya malah menunjukkan bahwa ekonomi harus dimiliki jika seorang laki-laki ingin berpoligami dan saat membahas sunah juga harusnya bisa menjadi penegas bahwa hal itu sudah tidak sesuai dengan sunah Rasul atau konteks mengapa poligami dilakukan. Karena sejarah juga menunjukkan hal tersebut bahwa Nabi selama menikah dengan Siti Khadijah tidak menikah lagi selama kurang lebih lima belas tahun. Hal ini sebetulnya bisa disampaikan sebagai dasar untuk menunjukkan bahwa poligami harusnya tidak dilakukan pada zaman sekarang. Fokus pada penekanan terakhir yang disampaikan adalah mengenai kesabaran dan keikhlasan seorang istri ketika dipoligami. Seorang perempuan harus melayani suaminya dan tidak demikian sebaliknya bahwa seorang perempuan atau istri pun sebenarnya juga punya hak untuk dilayani oleh suaminya. Karena pada pernyataan awal juga menunjukkan bahwa suami yang menyakiti istri juga akan menerima azab dari Allah dan termasuk golongan yang dibenci oleh Allah. Penjelasan ini harusnya disampaikan kembali ketika muncul pada akhir sesi tanya jawab namun hal ini tidak terjadi. Dalam hal ini terlihat wanita diharuskan untuk tunduk dan patuh kepada suami, sekalipun mereka disakiti dengan dipoligami. Tidak demikian sebaliknya, Mamah Dedeh tidak menyampaikan sebaliknya jika kaum lakilaki pun harusnya juga mengetahui kewajibannya terhadap sang istri, seperti memerhatikan perasaan istrinya jika ia poligami. Walaupun sempat pada saat tanya jawab menjelaskan bahwa wanita bisa menolak atau mau saat dipoligami. Karena poligami menunjukkan sakit batin dan psikologis dari seorang wanita, yang harusnya hal ini juga diperhatikan oleh sang suami. Maka terlihat bahwa seorang wanita tidak memiliki kuasa untuk menolak poligami yang ada justru perempuan harus menuruti dan patuh terhadap suami dengan dalil bahwa bisa jadi hal itu adalah takdir Allah dan juga anggapan itu merupakan kewajiban istri terhadap suami.

\section{Kesimpulan}

Dari penjelasan tersebut dapat diketahui bahwa subjek dalam ceramah tersebut didominasi oleh kaum laki-laki, kaum lakilaki muncul pada pembahasan awal poligami mengenai keadilan materi (pangan, sandang, papan), waktu, dan cinta, termasuk pula pada persoalan meminta ijin kepada istri untuk berpoligami. Sedangkan perempuan muncul sebagai subjek pada saat membahas mengenai ijin dari istri jika suaminya menikah lagi, pembahasan masalah keturunan serta masalah sunah Rasul.

Posisi laki-laki dan perempuan sebagai objek pembahasan, laki-laki ada menjadi objek pembahasan disinggung pada teks mengenai ijin dari istri jika suaminya menikah lagi, kemudian pada pembahasan masalah keturunan serta masalah sunah Rasul. Kemudian untuk perempuan sebagai objek muncul saat membahas keadilan 
papan, pangan, waktu, dan cinta, kemudian juga pada aspek kemampuan ekonomi, kemudian juga pada pembahasan mengenai ijin istri jika mau berpoligami serta pada penutup ceramah yang menunjukkan keikhlasan istri jika dipoligami.

Dari keseluruhan hasil ceramah jika dicermati lebih dalam Mamah Dedeh memiliki gambaran wacana terhadap posisi perempuan dalam poligami adalah sebagai pihak yang harus menerima dan berusaha untuk ikhlas jika dipoligami. Perempuan seperti tidak memiliki kuasa untuk menolak walaupun sempat dijelaskan bahwa perempuan bisa memilih, namun pada akhirnya Mamah Dedeh tetap menganggap bahwa perempuan memiliki kewajiban melayani suami. Hal tersebut menunjukkan bahwa perempuan tidak bisa menolak keinginan poligami sang suami. Kesimpulan tersebut didasarkan juga pada latar belakang keluarga dan juga pendidikan Mamah Dedeh yang hidup dalam keluarga agamis serta memiliki pengalaman hidup yang mengikuti dan melayani suaminya.

\section{Bibliografi}

Budiman, Andi. "Dialog Terbuka Poligami." Liputan6.com. 16 Agustus 2017. http://news.liputan6.com/read/134087/dialog-terbuka-poligami.

Daylailatu, Hasuna. "Profil Mamah Dedeh." Tabloidnova.com. 24 September 2009. http://tabloidnova.com/Selebriti/Profil/Mamah-Dedeh-2-Anak-Bedug-Jadi-Istri-AnakKiai.

Daylimotion. "Ceramah Mamah Dedeh Terbaru 8 Oktober 2015 - Poligami Bisakah Adil". Daylimotion.com. 6 Maret 2016 . http://www.dailymotion.com/video/x3957k5.

Eriyanto. Analisis Wacana. Yogyakarta: LKiS Yogyakarta, 2001.

Fathonah. "Telaah Poligami: Perspektif ulama populer dunia (dari ulama klasik hingga ulama kontemporer)." Al-Hikmah Jurnal Studi Kelslaman Vol. 5 No. 1, (2015): 13-37.

Fathoni, Mochammad. n.d. "Respon Pelaku Poligami di Kabupaten Kediri Prop. Jawa Timur Terhadap Pelaksanaan Poligami Dalam Perspektif Hukum Islam dan Hukum Positif." Tesis, UIN Sunan Ampel Surabaya.

Hikmah, Siti. "Fakta Poligami Sebagai Bentuk Kekerasan Terhadap Perempuan." Jurnal SAWWA Vol. 7. No.2 (2012): 1-20.

Kusuma, Wijaya. "Aktivis Perempuan Demo Tolak Poligami dan Nikah Siri". Kompas.com. 16 Agustus 2017. http://nasional.kompas.com/read/2013/03/08/1210469/aktivis.perempuan.demo.tolak. poligami.dan.nikah.siri.

Muhardiansyah, Yan. "Belasan Wanita Cantik Bercelana Jin Ketat Demo Tolak Poligami." Merdeka.com. 16 Agustus 2017. https://www.merdeka.com/peristiwa/belasan-wanitacantik-bercelana-jin-ketat-demo-tolak-poligami.

Nurrokim, Mohammad. "Analisis Brand Awareness dan Brand Association Acara Dakwah di Televisi." Jurnal Kajian \& Pengembangan Managemen Dakwah. Vol. 03. No. 02 (2013): 34-49. 
Prasetyo, Wisnu Agung. "Dr. Gina Puspita, Deklarator Klub Taat Suami: Poligami itu Bukan Suami yang Suruh." Tempo.co. $16 \quad$ Agustus 2017. https://m.tempo.co/read/news/2011/06/26/001343303/dr-gina-puspita-deklaratorklub-taat-suami-poligami-itu-bukan-suami-yang-suruh.

Rismawati, Shinta Dewi. "Persepsi Poligami di Mata Perempuan Pekalongan." Jurnal Muwazah, Vol. 6 No. 2 (2014): 249-263.

Sahril, Mohamad. "Begini Alasan Kampanye Kelompok Poligami Sakinah." pojoksatu.com. 16 Agustus 2017. http://pojoksatu.id/news/2015/03/27/begini-alasan-kampanyekelompok-poligami-sakinah/.

Sobur, Alex. Analisis Teks Media: Suatu Pengantar untuk Analisis Wacana, Analisis Semiotik, dan Analisis Framing. Bandung: Remaja Rosdakarya, 2009.

Sugiyono. Metode Penelitian Kuantitatif Kualitatif dan R\&D. Bandung: Alfabeta, 2012.

Sunaryo, Agus. "Poligami di Indonesia (Sebuah Analisis Normatif-Sosioligis)." Jurnal Studi Gender \& Anak Vol. 5. No.1 (2010): 143-167.

Tribunnews. "Wanita Lombok Demo Tolak Poligami Bayar Rp 1 Juta." Tribunnews.com. 16 Agustus 2017. http://wartakota.tribunnews.com/2014/10/24/wanita-lombok-demotolak-poligami-bayar-rp-1-juta.

Wartini, Atik. "Poligami : Dari Fiqh hingga Perundang-Undangan." Jurnal Studia Islamika Vol. 10. No.2, (2013): 237-368. 
Eko Agoes Setiawan 